\title{
The prevalence of Raynaud's syndrome in rheumatoid arthritis
}

\author{
G. J. CARROLL, K. WITHERS, AND C. E. BAYLISS
}

From the Department of Rheumatic Diseases, Royal Perth (Rehabilitation) Hospital, Selby Street, Shenton Park 6008, Western Australia

SUMMARY To test the validity of the putative association between Raynaud's syndrome and rheumatoid arthritis (RA) 277 patients with rheumatic disorders were questioned about coldinduced colour reactions in the extremities. The time to recover digital temperature after brief immersion in ice water was used to confirm the presence of Raynaud's syndrome. The prevalence of Raynaud's syndrome in the 148 patients with RA and the 59 patients with osteoarthritis was $2.7 \%$ and $5.1 \%$ respectively. It is concluded that Raynaud's syndrome is not a frequent accompaniment of RA, and it is suggested that in view of the close association between Raynaud's syndrome and certain other disorders, such as mixed connective tissue disease and scleroderma, when patients present with polysynovitis and Raynaud's syndrome special consideration should be given to these conditions.

In 1862 Maurice Raynaud ${ }^{1}$ described a clinical syndrome characterised by cold-induced colour changes in the hands. These changes are typically triphasic, beginning with pallor and progressing through cyanosis to terminal redness. Sensory disturbances frequently accompany these colour reactions.

The published criteria for the diagnosis of Raynaud's syndrome are variable and imprecise. Incomplete forms of the classical syndrome are often accepted as valid expressions of the same phenomenon.

Raynaud's syndrome has been described in many different diseases among which rheumatic diseases represent an important subset. Ever since C. L. Short and his colleagues ${ }^{2}$ reported a $10 \%$ incidence of vascular spasm in rheumatoid arthritis there has been a popular belief that Raynaud's syndrome has a special association with RA. This study was designed to test the validity of this putative association.

\section{Patients and methods}

During a 6-week period all of the patients who attended a rheumatic clinic at Royal Perth (Rehabilitation) Hospital were questioned by one of the

Accepted for publication 6 January 1981

Correspondence to Dr G. J. Carroll. authors about cold-induced colour reactions in the hands. If a reaction of any description occurred in both hands at least 3 times a year, the patient was considered to have satisfied the preliminary screening criteria for Raynaud's syndrome and was invited to attend a follow-up clinic, where a more detailed history was taken, a physical examination carried out, and a digital temperature recovery time test (DTRTT) performed. Seventeen of the 19 patients who met these criteria were followed up. One of the other 2 died in the interim period and the second had moved to a geographically remote area.

The duration of the patients' predominant illness, the onset of the symptoms of Raynaud's syndrome, the patients' smoking history, and any family history of Raynaud's syndrome were noted. In particular the patients were examined for evidence of peripheral obliterative arterial disease in the upper limbs, cutaneous vasculitis, and features of scleroderma.

The DTRTT was performed in accordance with the modified technique described by Porter et al. $^{3}$ The patient sat in a warm room for $\mathbf{3 0}$ minutes before the test. The room temperature was monitored and maintained between $23^{\circ} \mathrm{C}$ and $26^{\circ} \mathrm{C}$. The patient was seated and the left hand was placed in a supine position on the adjoining table. The skin temperature was recorded over the distal pulp of the left ring finger if this digit was involved; otherwise an involved digit was chosen. It was measured with a copper 
constan thermocouple and read from an Ellab spot galvanometer with a $0.2^{\circ} \mathrm{C}$ range of error. After recording the basal temperature the hand was immersed in ice for 20 seconds. It was then removed, dried promptly, and kept immobile while at the same site as before the skin temperature was measured at 1-minute intervals until it returned to the basal level or 30 minutes had elapsed. Definite Raynaud's syndrome was considered to exist only if the subject satisfied the preliminary screening criteria and the digital temperature recovery time was prolonged.

The diagnosis of the patient's condition was extracted from hospital case records.

\section{Results}

Of the 277 patients who were questioned 148 had rheumatoid arthritis (RA), 59 osteoarthritis (OA), 2 systemic lupus erythematosus, 1 mixed connective

Table 1 The number of patients in each diagnostic category and the proportion who met the preliminary criteria for a diagnosis of Raynaud's syndrome

\begin{tabular}{lrl}
\hline Diagnosis & Total number & $\begin{array}{l}\text { Number who met the } \\
\text { preliminary criteria for } \\
\text { Raynaud's syndrome }\end{array}$ \\
\hline Rheumatoid arthritis & 148 & 7 \\
Osteoarthritis & 59 & 7 \\
MCTD & 1 & 1 \\
SLE & 2 & 1 \\
Overlap syndrome & 1 & 1 \\
Other & 66 & 2 \\
\hline
\end{tabular}

MCTD = mixed connective tissue disease. $\mathrm{SLE}=$ systemic lupus erythematosus.

Table 2 Demographic data

\begin{tabular}{llrlll}
\hline Diagnosis & $\begin{array}{l}\text { Mean } \\
\text { age } \\
\text { (years) }\end{array}$ & $\begin{array}{l}\text { Total } \\
\text { number }\end{array}$ & Males & Females & $\begin{array}{l}\text { Females } \\
\%\end{array}$ \\
\hline $\begin{array}{l}\text { Rheumatoid } \\
\text { arthritis }\end{array}$ & 58.9 & 148 & 41 & 107 & $\begin{array}{l}72.9 \\
\text { Osteoarthritis }\end{array}$ \\
\hline 59.6 & 59 & 14 & 45 & 76.3 \\
\hline
\end{tabular}

tissue disease, and the remainder a variety of other rheumatic disorders. In each of these groups the number who satisfied the screening criteria for Raynaud's syndrome is shown in Table 1. All except patient 4 (in Table 3) were female. The mean ages and sex ratios in the RA and OA groups are displayed in Table 2.

The nature, duration, and onset of the symptoms of Raynaud's syndrome together with the basal digital skin temperature and digital temperature recovery time for each patient are shown in Tables 3,4 , and 5 . The complete recovery time profiles are displayed in Figs 1, 2, and 3. Patients 1, 2, 3, 5, 9, 11,12 , and 14 were considered to have a digital temperature recovery consistent with digital vasospasm and therefore Raynaud's syndrome.

In none of the 17 patients examined were there features of obliterative arterial disease, cutaneous vasculitis, or scleroderma. Two of the patients (2 and 4) were cigarette smokers. Only 1 patient (3) had a family history of Raynaud's syndrome. She first developed symptoms of this condition at puberty and did not develop rheumatoid arthritis

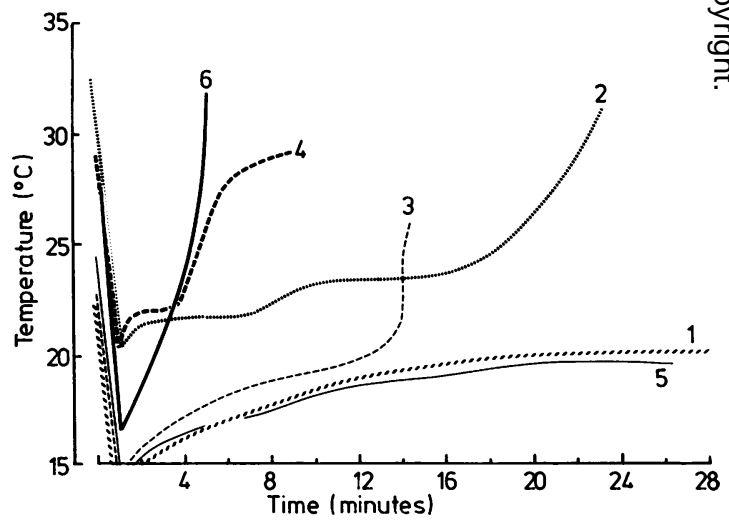

Fig. 1 Digital temperature recovery in the 6 patients with rheumatoid arthritis who met the screening criteria for Raynaud's syndrome.

Table 3 The clinical and laboratory features of the rheumatoid arthritis patients who satisfied the preliminary criteria for a diagnosis of Raynaud's syndrome

\begin{tabular}{|c|c|c|c|c|c|c|}
\hline Patient no. & Age & $\begin{array}{l}\text { Duration } \\
\text { of disease } \\
(y r)\end{array}$ & $\begin{array}{l}\text { Duration of } \\
\text { Raynaud's } \\
\text { syndrome }(y r)\end{array}$ & Colour reaction & $\begin{array}{l}\text { Basal } \\
\text { temperature } \\
\left(C^{0}\right)\end{array}$ & $\begin{array}{l}\text { Digital temperature } \\
\text { recovery time (min) }\end{array}$ \\
\hline $\begin{array}{l}1 \\
2 \\
3 \\
4 \\
5 \\
6\end{array}$ & $\begin{array}{l}59 \\
65 \\
53 \\
52 \\
36 \\
71\end{array}$ & $\begin{array}{r}10 \\
36 \\
7 \\
3 \\
7 \\
8\end{array}$ & $\begin{array}{r}1 \\
30 \\
42 \\
15 \\
5 \\
55\end{array}$ & $\begin{array}{l}\text { Pallor only } \\
\text { Pallor and cyanosis } \\
\text { Pallor and rubor } \\
\text { Pallor only } \\
\text { Cyanosis only } \\
\text { Pallor, cyanosis, } \\
\text { and rubor }\end{array}$ & $\begin{array}{l}22.5 \\
30.6 \\
24.8 \\
29.0 \\
24.5 \\
31.8\end{array}$ & $\begin{array}{r}>30 \\
23 \\
14 \\
9 \\
>30 \\
5\end{array}$ \\
\hline
\end{tabular}


Table 4 The clinical and laboratory features of the osteoarthritis patients who satisfied the preliminary criteria for a diagnosis of Raynaud's syndrome

\begin{tabular}{|c|c|c|c|c|c|c|}
\hline Patient no. & Age & $\begin{array}{l}\text { Duration } \\
\text { of disease } \\
\text { (yr) }\end{array}$ & $\begin{array}{l}\text { Duration of } \\
\text { Raynaud's } \\
\text { syndrome (yr) }\end{array}$ & Colour reaction & $\begin{array}{l}\text { Basal } \\
\text { temperature } \\
\left(C^{\circ}\right)\end{array}$ & $\begin{array}{l}\text { Digital temperature } \\
\text { recovery time (min) }\end{array}$ \\
\hline 7 & 58 & 5 & 10 & Pallor only & $30 \cdot 0$ & 2 \\
\hline 8 & 58 & 12 & 10 & $\begin{array}{l}\text { Pallor, cyanosis, } \\
\text { and rubor }\end{array}$ & $32 \cdot 5$ & 7 \\
\hline 9 & 79 & 10 & 40 & Pallor only & $23 \cdot 4$ & $>30$ \\
\hline 10 & 54 & 2 & 2 & $\begin{array}{l}\text { Pallor, cyanosis, } \\
\text { and rubor }\end{array}$ & $31 \cdot 6$ & 8 \\
\hline 11 & 46 & 6 & 2 & Pallor and cyanosis & $24 \cdot 8$ & $>30$ \\
\hline 12 & 43 & 15 & 2 & Pallor and cyanosis & $23 \cdot 2$ & 21 \\
\hline
\end{tabular}

Table 5 The clinical and laboratory features of the remaining group of patients who satisfied the preliminary criteria for a diagnosis of Raynaud's syndrome

\begin{tabular}{|c|c|c|c|c|c|c|}
\hline Patient no. & Diagnosis & $\begin{array}{l}\text { Duration } \\
\text { of disease } \\
(y r)\end{array}$ & $\begin{array}{l}\text { Duration of } \\
\text { Raynaud's } \\
\text { syndrome }(y r)\end{array}$ & Colour reaction & $\begin{array}{l}\text { Basal } \\
\text { temperature } \\
\left(C^{\circ}\right)\end{array}$ & $\begin{array}{l}\text { Digital temperature } \\
\text { recovery time (min) }\end{array}$ \\
\hline 13 & SLE & 5 & 12 & $\begin{array}{l}\text { Pallor, cyanosis, } \\
\text { and rubor }\end{array}$ & $29 \cdot 8$ & 16 \\
\hline 14 & MCTD & 4 & 4 & Pallor and rubor & $28 \cdot 0$ & $>\mathbf{3 0}$ \\
\hline 15 & Overlap syndrome & 6 & 4 & Cyanosis only & $26 \cdot 8$ & 12 \\
\hline 16 & $\begin{array}{l}\text { Polysynovitis of } \\
\text { uncertain origin }\end{array}$ & 4 & 4 & Pallor only & $33 \cdot 2$ & 3 \\
\hline 17 & $\begin{array}{l}\text { Polysynovitis of } \\
\text { uncertain origin }\end{array}$ & 5 & 3 & Pallor only & $33 \cdot 0$ & 3 \\
\hline
\end{tabular}

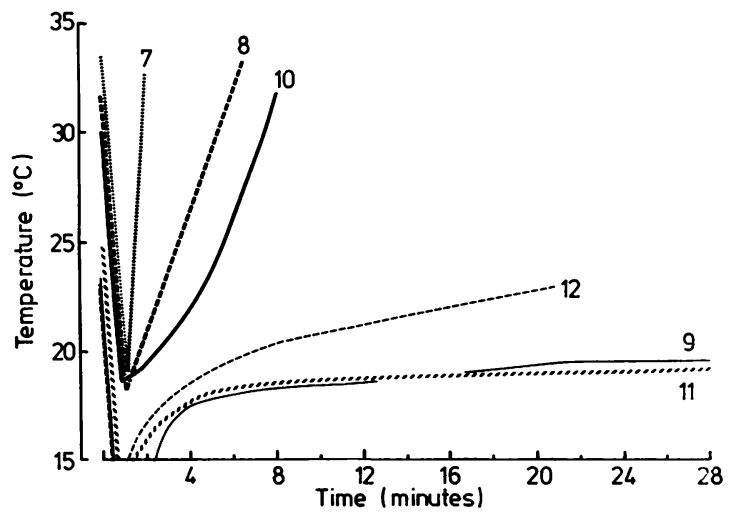

Fig. 2 Digital temperature recovery in the 6 patients with osteoarthritis who met the screening criteria for Raynaud's syndrome.

until 35 years later. One of her 3 daughters developed similar symptoms in adolescence. When tested she also had a delayed recovery in digital temperature. On these grounds a diagnosis of familial Raynaud's syndrome was preferred.

Four of the 148 patients with RA and 3 of the 59 patients with OA satisfied the criteria for definite Raynaud's syndrome. Thus the overall prevalence of this condition in the 2 groups was $2.7 \%$ and $5.1 \%$ for RA and OA respectively. However, since all the patients who met these criteria were female, the prevalence of Raynaud's syndrome is best

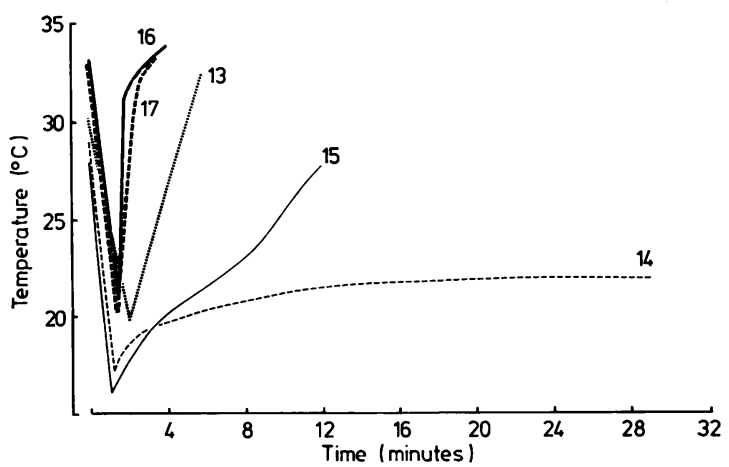

Fig. 3 Digital temperature recovery in those 5 patients with other rheumatic disorders who met the screening criteria for Raynaud's syndrome.

expressed as $3.7 \%$ among females with RA and $7 \cdot 1 \%$ among females with OA.

A close relationship was noted between a low basal digital skin temperature and a prolonged digital temperature recovery time. Regression analysis gave a correlation coefficient of -0.7776 . The regression equation where $x$ represents the basal skin temperature and $\mathrm{y}$ the digital temperature recovery time was $\mathrm{y}=80.52-2 \cdot 29 \mathrm{x}$. The $\mathrm{r}$ value was associated with a $T$ value of 4.789 with 15 degrees of freedom and is significant at the $0.1 \%$ level $(\mathrm{p}<0 \cdot 001)$. 


\section{Discussion}

Raynaud's syndrome is not necessarily a straightforward diagnosis. It is uncommon for the clinician to witness a typical attack, there is no reliable provocative manoeuvre, and in many cases there are no typical signs. The diagnosis therefore usually rests on the history, but in many patients a clear history is difficult to elicit. Some are not astute observers and fail to perceive the precise sequence of cold-related colour changes. In others a sensitive awareness of physiological changes in hand colour may result in an enthusiastic response to leading questions, thereby confounding the inquiry.

Whenever a clinical diagnosis is in doubt, a laboratory test which takes account of the pathogenesis of the disorder is usually of most assistance. Ideally, such a test should also be safe, noninvasive, inexpensive, and simple. Transient ice water exposure and thermometry meet these requirements. Porter and his colleagues have evaluated the recovery in digital temperature following brief ice-water exposure and found a delay beyond 20 minutes in $92 \%$ of subjects with Raynaud's syndrome and only $5 \%$ of ostensibly healthy controls. ${ }^{3}$ Charles and Carmick employed the same technique to record a therapeutic response in patients with Raynaud's syndrome who were treated with griseofulvin. ${ }^{4}$ Although the predictive value of the digital temperature recovery test has not been studied extensively, it was decided to use it in this study because of the high sensitivity and specificity reported by Porter et al. ${ }^{3}$

Regardless of whether the diagnosis of Raynaud's syndrome was made on the basis of the screening criteria alone or together with the DTRTT the prevalence of Raynaud's syndrome among patients with RA was no greater than in those with OA. The discordance between our results and those of Short et al., ${ }^{2}$ whose single study constitutes the only evidence on which an association between Raynaud's syndrome and RA appears to be founded, may be explained by differences in patient selection. Short and his collaborators studied 293 patients believed to be suffering from rheumatoid arthritis who were admitted to the Massachusetts General Hospital between 1930 and $1936 .{ }^{2} 11 \cdot 3 \%$ of these patients and $2.7 \%$ of the 293 controls reported vascular spasm. Since then a positive association between Raynaud's syndrome and RA has been assumed. It is possible that some of the patients in the RA group of Short et al. may have been suffering from other rheumatic diseases such as mixed connective tissue disease in which the incidence of Raynaud's syndrome is approximately $85 \%{ }^{5}$ The inclusion of patients with this and similar disorders would have resulted in a disproportionately high prevalence of Raynaud's syndrome.

In view of the infrequent coincidence of Raynaud's syndrome and RA and the strong association of Raynaud's syndrome with mixed connective tissue disease and scleroderma, it is suggested that when patients present with polysynovitis and Raynaud's syndrome special consideration should be given to these disorders.

Although Porter et al. did not find any relationship between the basal digital skin temperature and the digital temperature recovery time, in this study a negative correlation was observed. In particular patients with basal temperatures below $27^{\circ} \mathrm{C}$ generally had vasospastic recovery time curves consistent with the presence of Raynaud's syndrome. The predictive value of this observation requires further evaluation. The finding of low basal temperatures suggests the possibility of underlying occlusive arterial disease. Obliterative digital arterial disease has been convincingly demonstrated in a surprisingly high percentage of patients with Raynaud's syne drome, but whether it precedes or complicates the disturbance in digital vascular reactivity to cold conjectural. $^{6}$

We are indebted to the Department of Physiology in the University of Western Australia for the provision of equipment used in this study. We also thank Mrs Joy Bourne and the Royal Perth Hospital, Department of Medical Illustration, for their assistance in the preparation of the manuscript.

\section{References}

1 Raynaud M. De l'asphyxie locale et de la gangréne symétrique des extrémités (1862). In: Selected Mònographs, translated by Thomas Barlow. London: New Sydenham Society, 1888.

2 Short C L, Bauer W, Reynolds W E. Rheumatoid Arthritis. Harvard: University Press, 1957; 261-9.

3 Porter J M, Snider R L, Bardana E M, et al. The diagnosis and treatment of Raynaud's phenomenon. Surgery 1975 77: 11-23.

4 Charles C, Carmick E S. Skin temperature changes in Raynaud's disease after griseofulvin. Arch Dermatol 1970; N $101: 331-6$.

5 Sharp G C, Irvin W, Tan E M, et al. Mixed connective $N$ tissue disease - an apparently distinct rheumatic disease syndrome associated with a specific antibody to an $\omega$ extractable nuclear antigen (E.N.A.). Am J Med 1972; 52: 148-59.

6 Porter J M, Bardana E J, Bauer M D, et al. The clinical significance of Raynaud's syndrome. Surgery 1976; 80: 756-64. 